\title{
Economic Viability of the Tista River Sand Deposits in Bangladesh An Overview
}

\author{
M. A. Rahman*, M. N. Zaman, P. K. Biswas, M. S. Sultana \\ Institute of Mining, Mineralogy and Metallurgy, Bangladesh Council of Scientific and Industrial \\ Research, Science Laboratory Road, Khonjonpur, Joypurhat 5900, Bangladesh
}

Received 16 November 2016, accepted in final revised form 22 January 2017

\begin{abstract}
The Tista River originates from the Himalaya Mountain, flows through Bangladesh and makes itself as the largest tributary of the Brahmaputra-Jamuna River, having huge sand deposits with valuable minerals. The present work implies economic viability of the Tista River sand deposits measuring heavy mineral concentration and comparing with other established deposits and marking the cut-off grade and prices of these minerals. The study shows that the average content of heavy minerals is $8.26 \%$, containing garnet, ilmenite, magnetite, rutile, zircon and micas. The selected valuable oxides in the form of minerals are $\mathrm{SiO}_{2}, \mathrm{MgO}, \mathrm{K}_{2} \mathrm{O}$ and rare earth elements. The commendable amount of $\mathrm{SiO}_{2} 71.72$ wt\% makes it feasible as raw material in the glass factory. Another valuable oxide is $\mathrm{K}_{2} \mathrm{O}$ amounted $2.53 \mathrm{wt} \%$ (price per ton in US\$ 350-400) makes it praiseworthy. The valuable elements found in deserving quantities are $\mathrm{Ba}, \mathrm{Rb}, \mathrm{Th}, \mathrm{V}, \mathrm{Cs}, \mathrm{Cr}, \mathrm{Ni}$ and $\mathrm{Co}$. The remarkable finding of this study is Thorium (Th) measured $28 \mathrm{gm} / \mathrm{ton}$ of bulk sand. According to Nobel laureate Carlo Rubbia, thorium (Th) can produce 200 times more electricity than uranium and more environment friendly. So it is economically feasible to take proper initiative to set up mining for sand processing.
\end{abstract}

Keywords: Cut-off grade; Heavy mineral; Thorium; Uranium; Environment.

(c) 2017 JSR Publications. ISSN: 2070-0237 (Print); 2070-0245 (Online). All rights reserved. doi: http://dx.doi.org/10.3329/jsr.v9i2.30374 J. Sci. Res. 9 (2), 219-233 (2017)

\section{Introduction}

Mineral sands are different to most commodities though they share similarities with other commodity types, such as the importance of quality constraints of iron ore and coal or the importance of physical properties of say diamonds. The term 'mineral sands' normally refers to concentrations of heavy minerals (HM) in an alluvial (old beach or river system) environment and commonly mined for valuable heavy minerals. These heavy minerals are chemically stable, are resistant to abrasion and can withstand digenetic alteration with the exception of ilmenite, which can be beneficiated in titanium grade under certain conditions [1].

\footnotetext{
* Corresponding author: aminur08@gmail.com
} 
The exploration, development, mining and processing of mineral sands is a typical within the resource sector, because at virtually every stage it is possible to visually estimate the grade and composition of the HM and valuable heavy mineral (VHM). However, the ESCAP of the United Nations published a report on the mineral sands in Asia and the Pacific, Volume 4, in 1990. According to the abstract of the publications, throughout the most of this century, countries of the ESCAP region have been a major world source of titanium, zirconium, and rare earth ores, and this position is likely to be maintained in the 21 st century. Bangladesh as being a ESCAP country, has a role to play to fulfill the desire of the ESCAP publication on the mineral sands.

Bangladesh has many HM sands occurrences along the southern and southeastern coastlines of the country where the heavy minerals occur in shoreline placer deposits and in associated sand dunes [2-5]. These shoreline deposits are typically high grade and can contain up to 20 to $25 \%$ (by weight) HM [5]. Current and past mineral sands development opportunities in Bangladesh have focused on developing these high-grade coastal sand deposits. However, many of the development opportunities are limited as some deposits are located in populated, environmentally sensitive areas and some of the contained VHM minerals have high levels of radioactivity. Both make exploitation potentially problematic. There is however, an emerging potential for sourcing HM sands from the wide spread river sand placer deposits associated with some of the extensive river systems in Bangladesh [6,7].

In Bangladesh the mineral sands commonly found in the coastal areas and proved as mineable [4]. But in the inland, no sand deposit has yet been proved to be as mineral sands excepting some glass-sands deposits. It is notable that one of the objectives of the study is to identify the industrial uses of the minerals occurring in the Tista River.

A deposit of sands in the Tista River, a Himalayan one and the largest tributary of the Brahmaputra River in Bangladesh, which falls near Chilmari River port on the right bank of the Mighty Brahmaputra River, a sand bedded braided river (Fig. 1). Any sand deposit elsewhere even in Bangladesh may be considered as a resource if that contains valuable minerals or elements of existing current cut-off grade, having the acceptable quality of the minerals or elements.

Apart from defining the volume of potentially viable sands in a HM deposit, the critical components in mineral resource assessment of HM deposits include; identifying the mineralogical assemblage, quantifying the HM grade, and assessing the quality of the contained mineral species for potential end-use applications. Specifically this study examines the mineralogy, composition and grade of the HM sands and setting up a conceptual 200 tph mining and processing plant for economic viability of the Tista River sand. 


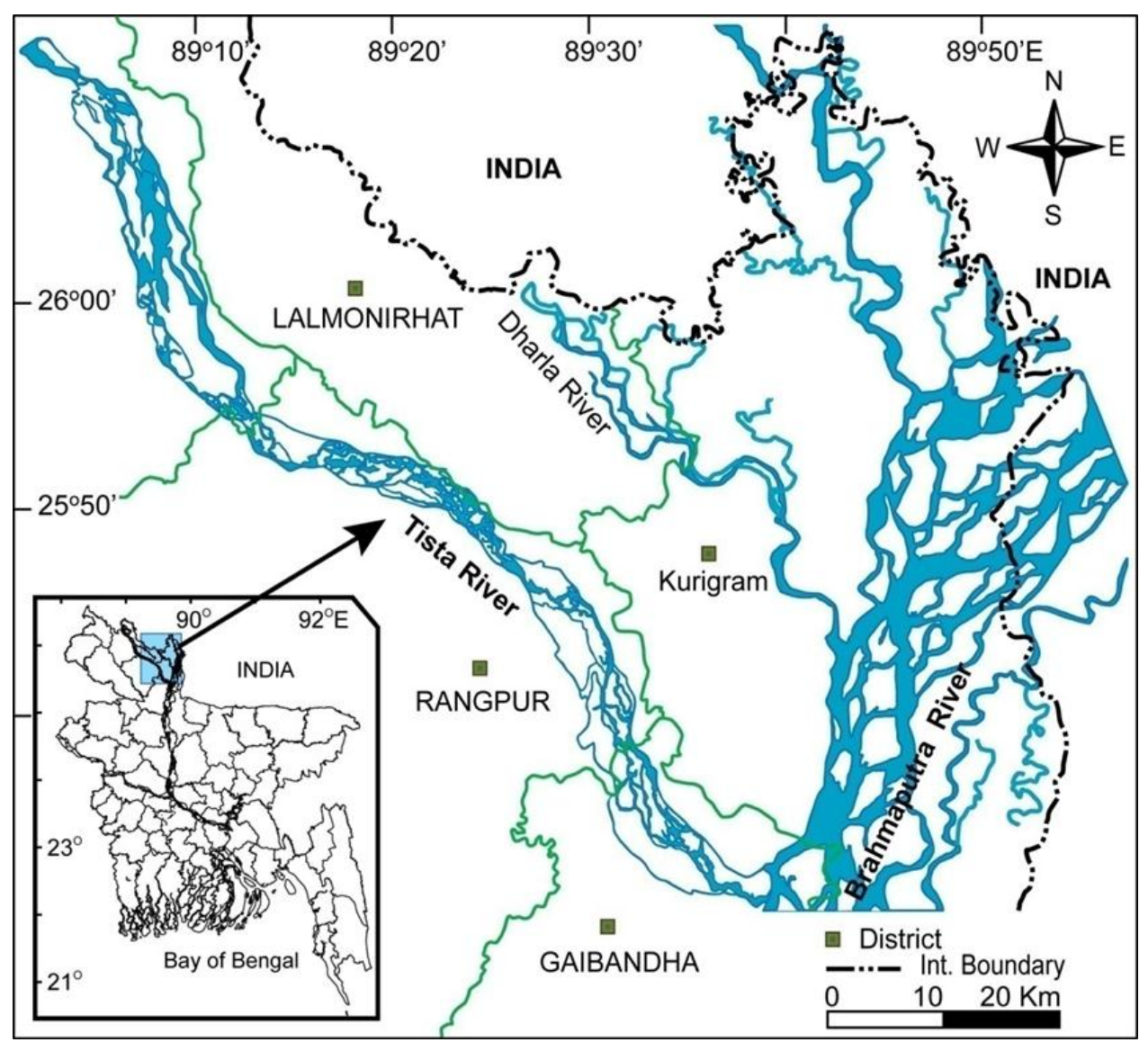

Fig. 1. Location map of Tista River basin.

\section{Experimental}

\subsection{Reserves of sand deposits in the Tista River valley}

The area is covered with alluvial deposits and those have been classified broadly as alluvial silt and alluvial sand. Alluvial silt is light grey to medium grey fine sandy to clayey silt, commonly to poorly stratified. Average grain sizes decreases away from the main channel and chiefly deposited in flood basins and inter streams areas. This unit includes small back swamp deposits and varying amounts of thin interstratified sand deposited during episodic or unusually large floods. Alluvial sand is light grey to brownish grey, coarse to fine silty sand. Sand is generally sub-rounded, constitutes channel bars and levee deposits along the rivers [8].

The sand samples were collected from the newly sand bars from near Kownia Tista Rail Bridge to Hatibanda, covering the length of about 30 kilometers of the Tista River. 
The depth of the collected samples varies from 10 to 20 meters. The elevation of the landmasses ranges from 51 meters to 54 meters above mean sea level. The bed level of the Tista River ranges from 50 meters to 53 meters above the mean sea level [9]. The literature review suggests that the Tista (Teesta) in Bangladesh is about 177 kilometers and the width varies from 300 to 550 meters and the average is 425 meters. The area has a distinct geomorphic character and the unit has been designated as the Tista River flood plain [10] and the assumed area covered by the sand deposits is about 7,500 hectares. The present day economic zone of sand deposits is about 10 meters depth and rest is of subeconomic zone.

The bed materials of the Tista River consist of the fine sand without any binding material and mean diameter of the bed load ranges from $0.15 \mathrm{~mm}$ to $0.33 \mathrm{~mm}$. Grain-size analysis of seventy two samples of bed load material indicated a range in median size from $0.340 \mathrm{~mm}$ (fine sand) to $0.028 \mathrm{~mm}$ (silt), with an average of $0.172 \mathrm{~mm}$. [11]. In the river flood plain, there is a gravel bed which is considered to be late quaternary basal gravel bed in alluvial lowland. The sediments that overlay the gravel bed are roughly subdivided into upper fine and lower coarse parts. The sediments of lower coarse part mainly consist of sand with gravel and the upper fine part mainly consists of silty sediments. The sediment of the upper member was deposited during the period of ca 10,000 - ca 6,000 - 5,000 B.P [12].

Economic zone $(10 \mathrm{~m})$ :

The total volume of the sand deposits $=7,500$ (hectares) $\mathrm{X} 10,000$ (square meters) $\mathrm{X} 10$ meters

$=750$ million cubic meters

The volume of dry sand deposit $\quad=750$ million cubic meters X $80 \%$ (20\% pore space filled with water) $=600$ million cubic meters

The total deposits in tonnage $\quad=600 \times 2.65$ (S.G of quartz which is $70 \%$ of the bulk deposit)

$=1590$ million metric tons

On an average, each hectare of land per one meter thickness contains 210,000 metric tons of sand deposits. Assumed 7,500 hectares of Tista River valley contains 1.5 billion metric tons of dry sand deposits up to the depth of 10 meters. On this basis, it is comparable with Cooljarloo Mineral Sands Mine of Australia and can last for 100 years.

\subsection{Methodology}

During field session on the river bank and char area of the Tista River site, the surface and core samples were closely examined, to identify the variation of grain size based on gross lithology, mineralogy, color, shape and size. Based on the above characteristics the collected samples were stored in polybag, labeled with station number, coordinate, serial 
number etc. A total 288 samples collected from 24 locations (Table 1) on the river bank and char area of the Tista River from the surface to 25 feet depth (using tube well boring).

Samples were shaking with shaking table (for light and heavy mineral separation) as well as heavy minerals were separated from sand fractions and bulk sediments by gravity settling in bromoform with a specific gravity of 2.89. The identification of heavy minerals was made optically by using a polarizing microscope and binocular microscope (under transmitted and reflected light).

Table 1. Hand held GPS based co-ordinate of the sampling point.

\begin{tabular}{cccccc}
\hline Station & Latitude & Longitude & Station & Latitude & Longitude \\
\hline 1 & $25^{\circ} 33.278^{\prime} \mathrm{N}$ & $89^{\circ} 36.466^{\prime} \mathrm{E}$ & 13 & $25^{\circ} 49.994^{\prime} \mathrm{N}$ & $89^{\circ} 24.432^{\prime} \mathrm{E}$ \\
2 & $25^{\circ} 37.657^{\prime} \mathrm{N}$ & $89^{\circ} 32.688^{\prime} \mathrm{E}$ & 14 & $25^{\circ} 50.553^{\prime} \mathrm{N}$ & $89^{\circ} 23.435^{\prime} \mathrm{E}$ \\
3 & $25^{\circ} 41.340^{\prime} \mathrm{N}$ & $89^{\circ} 32.312^{\prime} \mathrm{E}$ & 15 & $25^{\circ} 50.995^{\prime} \mathrm{N}$ & $89^{\circ} 23.261^{\prime} \mathrm{E}$ \\
4 & $25^{\circ} 44.635^{\prime} \mathrm{N}$ & $89^{\circ} 30.526^{\prime} \mathrm{E}$ & 16 & $25^{\circ} 52.153^{\prime} \mathrm{N}$ & $89^{\circ} 15.608^{\prime} \mathrm{E}$ \\
5 & $25^{\circ} 45.635^{\prime} \mathrm{N}$ & $89^{\circ} 28.191^{\prime} \mathrm{E}$ & 17 & $25^{\circ} 55.618^{\prime} \mathrm{N}$ & $89^{\circ} 10.724^{\prime} \mathrm{E}$ \\
6 & $25^{\circ} 46.218^{\prime} \mathrm{N}$ & $89^{\circ} 27.430^{\prime} \mathrm{E}$ & 18 & $25^{\circ} 59.002^{\prime} \mathrm{N}$ & $89^{\circ} 08.203 ' \mathrm{E}$ \\
7 & $25^{\circ} 46.640^{\prime} \mathrm{N}$ & $89^{\circ} 27.390^{\prime} \mathrm{E}$ & 19 & $26^{\circ} 01.570^{\prime} \mathrm{N}$ & $89^{\circ} 07.050^{\prime} \mathrm{E}$ \\
8 & $25^{\circ} 47.654^{\prime} \mathrm{N}$ & $89^{\circ} 26.477^{\prime} \mathrm{E}$ & 20 & $26^{\circ} 03.101^{\prime} \mathrm{N}$ & $89^{\circ} 08.150^{\prime} \mathrm{E}$ \\
9 & $25^{\circ} 47.990^{\prime} \mathrm{N}$ & $89^{\circ} 26.019^{\prime} \mathrm{E}$ & 21 & $26^{\circ} 04.641^{\prime} \mathrm{N}$ & $89^{\circ} 08.153^{\prime} \mathrm{E}$ \\
10 & $25^{\circ} 48.530^{\prime} \mathrm{N}$ & $89^{\circ} 25.759^{\prime} \mathrm{E}$ & 22 & $26^{\circ} 06.938^{\prime} \mathrm{N}$ & $89^{\circ} 07.295^{\prime} \mathrm{E}$ \\
11 & $25^{\circ} 48.8077^{\prime} \mathrm{N}$ & $89^{\circ} 25.040^{\prime} \mathrm{E}$ & 23 & $26^{\circ} 08.527^{\prime} \mathrm{N}$ & $89^{\circ} 06.382^{\prime} \mathrm{E}$ \\
12 & $25^{\circ} 49.031^{\prime} \mathrm{N}$ & $89^{\circ} 24.750^{\prime} \mathrm{E}$ & 24 & $26^{\circ} 10.001^{\prime} \mathrm{N}$ & $89^{\circ} 04.202^{\prime} \mathrm{E}$ \\
\hline
\end{tabular}

\subsubsection{Mineralogical Study}

For detailed mineralogical study total 18 samples for thin sections and ore reflected block were prepared almost two pieces for each sample. The thin sections and ore block were prepared in the Mineralogy laboratory of the Institute of Mining, Mineralogy and Metallurgy (IMMM), Bangladesh Council of Scientific and Industrial Research (BCSIR), Joypurhat, Bangladesh.

\subsubsection{Preparation of thin section slides and ore block}

To prepare slabs, the loose samples were mounted with araldite resin and araldite hardener $(2 \mathrm{~cm} \times 2 \mathrm{~cm} \times 2 \mathrm{~cm}$ ). One side of the slab was polished by a grinding machine (Power Pro 4000, Buehler GmbH, Germany) and further on a glass plate using 400 grade and after rising 600 grade carborandum powder with water to obtain a smooth and flat surface. The polished surface was then rubbed with running water to remove carborandum and later dried. In order to make an adhesive glue, araldite resin and araldite hardener were mixed in a ratio of 1:1 and diluted with toluene to reduce its viscosity (glue 30\%, toluene $70 \%$ ). Using araldite glue on the polished surface, the slabs were mounted on clean microscope slides carefully in order to remove excess glue and air bubbles. Then placed at 
room temperature for $72 \mathrm{~h}$ till the slab fixed to glass slide. The open face was cut by a sample cutting device (Petro Thin, Buehler GmbH, Germany). The slab then grinned by a grinding machine until light could pass through the microscopic slide. Both the slab and ore block was then rubbed on different diamond polishing paper. A polarizing microscope was used regularly used to check the thickness $(0.03 \mathrm{~mm}$. $)$ during rubbing in order to judge by examining the birefringence of quartz (first order gray color) and ore block was checked with reflected microscope. Finally the slide was washed with acetone and labeled with station and sample number.

\subsubsection{Microscopic study}

The mineralogical study of the Tista River sand has been carried out using MEIJI ML 9000 Polarizing, MEIJI ML 7000 Reflected and MEIJI EMZ-5TR microscope, made by Japan. The minerals were identified, counted and measured along with ten to fifteen suitably spaced traverses. The every mineral countable in the sample: Opaque (such as Ilmenite) and Non Opaque (such as Zircon, Kyanite, etc.) were estimated by counting a minimum of 200 grains by the ribbon method [13]. The color, crystal shape and size and other characteristics of the minerals and relative abundance were carefully examined from the view sections (microscopic grain counting), thin sections and ore blocks. Photographs have been taken by using COOLPIX camera attached with the microscope.

\subsubsection{X-ray fluorescence spectrometer study}

A total of 18 samples have been selected for XRF analysis (major elements $\mathrm{SiO}_{2}, \mathrm{Al}_{2} \mathrm{O}_{3}$, $\mathrm{TiO}_{2}, \mathrm{CaO}, \mathrm{MgO}, \mathrm{Na}_{2} \mathrm{O}, \mathrm{K}_{2} \mathrm{O}, \mathrm{Fe}_{2} \mathrm{O}_{3}{ }^{\mathrm{t}}, \mathrm{P}_{2} \mathrm{O}_{5}$ etc. and trace elements $\mathrm{Mn}, \mathrm{Ba}, \mathrm{Cu}, \mathrm{Rb}, \mathrm{Sr}, \mathrm{V}$, $\mathrm{Zr}, \mathrm{Hf}, \mathrm{Sc}$, Th, and U etc.).

The selected samples were crushed for 20 minutes in a planetary ball mill (PM-200, Retsch, Germany) to make powder form in well mixing conditions. The powder samples were then pulverized in a pulverizer machine. The finely ground powder $(<100 \mu \mathrm{m})$ was then put in a porcelain crucible and dried at $1000^{\circ} \mathrm{C}$ in an oven overnight to remove moisture. The dried powder samples were mixed with binder (steric acid: sample at a ratio of 1:10) and pulverized for two minutes. The resulting mixture was spooned into an aluminum cap $(30 \mathrm{~mm})$. The cap was sandwiched between two tungsten carbide pellets using a manual hydraulic press with $10-15$ tons $/ \mathrm{in}^{2}$ for $2 \mathrm{~min}$ and finally pressure was released slowly. The pellet was then ready for X-ray analysis. The elements were determined by X-ray fluorescence (XRF) spectrometer method using Rigaku ZSX Primus $\mathrm{XRF}$ machine equipped with an end window $4 \mathrm{~kW} \mathrm{Rh}$-anode $\mathrm{X}$-ray tube. The heavy and light elements were determined using $40 \mathrm{kV}$ voltage with $60 \mathrm{~mA}$ current and $30 \mathrm{kV}$ and $100 \mathrm{~mA}$ current respectively. The standards used in the analyses are the Geological Survey of Japan (GSJ) Stream Sediments (JSD 1, JSD 2 and JSD 3) and USGS Rock Standards (AVG 2, BCR 2, BHVO 2, BIR 1 and GSP 2). Analytical uncertainties for XRF major and minor elements are $\sim 2 \%$ and trace elements are $<10-15 \%$. 


\subsubsection{Process costing}

The heavy mineral concentrate (HMC) from a floating spiral concentrator ('Wet Concentration Plant', WCP) will be pumped to the mineral separation plant (MSP) where it will be dewatered and stockpiled for batch processing in the MSP. The primary test work program has been completed at IMMM, BCSIR with the aim being to maximize recovery and product quality. Test work results indicate a product mix of zircon, ilmenite, rutile, garnet and titano-magnetite products is feasible. The overall recovery for HM was $86 \%$. The flow sheets for the mine and WCP are based on mass balances using a nominal feed tonnage of $200 \mathrm{t} / \mathrm{h}$ from the dredge and a plant feed heavy mineral grade of $2.0 \%$. The mineral separation plant consists of three separate circuits: wet circuit, zircon dry circuit and ilmenite dry circuit. The process cost is based on current mining and mineral sands industry flow sheets and recent laboratory test works on the sand sample sourced from the Tista River basin.

\section{Results and Discussion}

The Tista River is a Himalayan river, it is sand bedded and has perpetual source of sediments. Bangladesh has constructed a barrage on the river. During the wet season, the river has high water flow as well as sediment load. In a preliminary study, it appears that the sand deposits may be found in an area of at least 7,500 hectares with an average thickness of 10 meters and such available sand deposit is about 1.5 billion metric tons. It is sufficient reserves of sand deposits eligible for mining if other factors support. The average content of heavy minerals is $8.26 \%$.

The grain size of the sand deposit is such that $99.92 \%$ of the sediments pass through the 20 mesh. The sand deposits suitable for glass making should pass through 20 mesh. The sand deposits should be iron and chromium free. Generally, in mineral sands mining processes all heavy minerals are separated as concentrate and the iron and chromium minerals would be removed as magnetic minerals and the middling's and tailings would have more $\mathrm{SiO}_{2}$ and would be of high grade silica sand. In the mineral sand industry, if the percentage of Valuable Heavy Minerals (VHM) is only $1 \%$ of the total heavy minerals (THM) then it is considered as mineable. The valuable heavy minerals are ilmenite, leucoxene, rutile and zircon in the Tista River sand deposits. In the bulk samples, the percentage of VHM is 1.83 and it is $22.155 \%$ of the heavy minerals and the rest is trash. The valuable heavy minerals are garnet, ilmenite, leucoxene, magnetite, rutile, zircon and micas with reference to the current cut-off grade (Table 2). 
Table 2. The valuable heavy minerals in the Tista River sand deposits with reference to the current cut-off grade and prices in US\$ per ton.

\begin{tabular}{|c|c|c|c|c|c|c|c|}
\hline $\begin{array}{l}\text { Average } \\
\text { content } \\
\text { of Total } \\
\text { heavy } \\
\text { minerals } \\
\text { (THM) } \\
\text { in } \%\end{array}$ & $\begin{array}{l}\text { Expected } \\
\text { Cut-off grade } \\
\text { of valuable } \\
\text { heavy } \\
\text { minerals in } \\
\text { the THM in } \\
\%\end{array}$ & $\begin{array}{l}\text { Name of } \\
\text { mineral }\end{array}$ & $\begin{array}{l}\text { Content } \\
\text { of } \\
\text { mineral } \\
\text { in } \%\end{array}$ & $\begin{array}{l}\text { Existing } \\
\text { Cut-off } \\
\text { grade }\end{array}$ & $\begin{array}{l}\text { Expected } \\
\text { Cut-off } \\
\text { grade }\end{array}$ & $\begin{array}{l}\text { Price of } \\
\text { mineral } \\
\text { in US \$ } \\
\text { per ton }\end{array}$ & Comment \\
\hline \multirow{9}{*}{8.26} & \multirow{9}{*}{1} & Garnet & 0.74 & 6.11 & $\begin{array}{l}\text { Not } \\
\text { known }\end{array}$ & $75-210$ & $\begin{array}{l}\text { It may be } \\
\text { co-product. }\end{array}$ \\
\hline & & Ilmenite & 0.58 & 3.53 & $>10$ & 110 & $\begin{array}{l}\text { It may be } \\
\text { co-product. }\end{array}$ \\
\hline & & Leucoxene & 0.19 & 1.67 & $>1$ & 840 & $\begin{array}{l}\text { It may be } \\
\text { main } \\
\text { product. }\end{array}$ \\
\hline & & Magnetite & 0.14 & 1.66 & $\begin{array}{l}\text { Not } \\
\text { known }\end{array}$ & 84 & \multirow{5}{*}{$\begin{array}{l}\text { It may be } \\
\text { co-product. } \\
\text { It may be } \\
\text { main } \\
\text { product. } \\
\text { It may be } \\
\text { used as } \\
\text { vermiculite. }\end{array}$} \\
\hline & & Rutile & 0.13 & 1.074 & $\begin{array}{l}\text { Not } \\
\text { known }\end{array}$ & 840 & \\
\hline & & Zircon & 0.19 & 1.569 & $>1$ & 1050 & \\
\hline & & Micas & 4.54 & 37.50 & $\begin{array}{l}\text { Not } \\
\text { known }\end{array}$ & 109 & \\
\hline & & REE & 0.0087 & & & & \\
\hline & & $\begin{array}{l}\text { Dark } \\
\text { minerals }\end{array}$ & 1.7 & $\begin{array}{l}\text { Not } \\
\text { known }\end{array}$ & $\begin{array}{l}\text { Not } \\
\text { known }\end{array}$ & $\begin{array}{l}\text { Not } \\
\text { known }\end{array}$ & $\begin{array}{l}\text { Those may } \\
\text { be the } \\
\text { sources of } \\
\text { valuable } \\
\text { elements. }\end{array}$ \\
\hline
\end{tabular}

Source: Mineral commodity summaries 2016 of U.S. Geological Survey.

The heavy minerals suite of the Tista River sand deposits contains $\mathrm{Ba}, \mathrm{Sr}, \mathrm{Th}, \mathrm{V}, \mathrm{Mg}$. $\mathrm{Ni}, \mathrm{Co}$ and REE and those are found in the trash and the light elements are $\mathrm{Rb}, \mathrm{Cs}$ and $\mathrm{K}$ (Table 3). Valuable light elements like $\mathrm{Rb}$ and $\mathrm{Cs}$ are occurring in the tailings which are mainly feldspars. Feldspars rich in rubidium, is valuable and those can be separated by froth floatation [14]. The minerals in the form of oxides are $\mathrm{SiO}_{2}, \mathrm{MgO}, \mathrm{K}_{2} \mathrm{O}$ and REE.

Table 3. Some selected elements and oxides found in the Tista river sand deposits in Bangladesh.

\begin{tabular}{llllll}
\hline $\begin{array}{l}\text { Name of } \\
\text { oxide }\end{array}$ & $\begin{array}{l}\text { Name of } \\
\text { element }\end{array}$ & $\begin{array}{l}\text { Content } \\
\text { wt. \% }\end{array}$ & $\begin{array}{l}\text { Price per ton } \\
\text { in US\$ }\end{array}$ & $\begin{array}{l}\text { Price per gram } \\
\text { in US \$ }\end{array}$ & Comment \\
\hline $\mathrm{SiO}_{2}$ & & 71.78 & 87 & & $\begin{array}{l}\text { A glass factory uses this } \\
\text { as raw material in float } \\
\text { glass sheet industry or } \\
\text { amorphous solar panel. }\end{array}$ \\
& & 2.53 & 635 & & \\
$\mathrm{~K}_{2} \mathrm{O}_{5}$ & & & & \\
\hline
\end{tabular}




\begin{tabular}{llllll}
\hline $\begin{array}{l}\text { Name of } \\
\text { oxide }\end{array}$ & $\begin{array}{l}\text { Name of } \\
\text { element }\end{array}$ & $\begin{array}{l}\text { Content } \\
\text { wt. \% }\end{array}$ & $\begin{array}{l}\text { Price per ton } \\
\text { in US\$ }\end{array}$ & $\begin{array}{l}\text { Price per gram } \\
\text { in US \$ }\end{array}$ & Comment \\
\hline & $\mathrm{Ba}$ & 0.0272 & 2,360 & & $12-25$ \\
& $\mathrm{Rb}$ & 0.0125 & & & \\
& $\mathrm{Sr}$ & 0.0106 & 6,860 & 65 & \\
& $\mathrm{Th}$ & 0.0028 & & 10 & \\
& $\mathrm{~V}$ & 0.0040 & & $65-100$ & \\
& $\mathrm{Cs}$ & 0.0005 & & & \\
& $\mathrm{Cr}$ & 0.1342 & 10,000 & 30 & \\
$\mathrm{REE}$ & $\mathrm{Ni}$ & 0.0032 & & & \\
& $\mathrm{Co}$ & 0.0087 & 2,258 & & \\
\hline
\end{tabular}

Source: Mineral commodity summaries 2016 of U.S. Geological Survey.

The literature review suggests that separation of heavy minerals may be most primitive and most modern. Simple methods are panning, Bolivian hand jigging and using Chinese palong [15]. In those methods of mineral sands mining mass participation is possible. During field work, the scientists of the institute observed that most of year, the depth of water remains shallow and lateral erosion is active. Both primitive and most modern methods of mining mainly open pit mining would be possible.

In the age of transformation, a waste of mining may be usable. The Bangladesh Water Development Board (BWDB) has been working on the taming the rivers and the most notorious one is the Tista River. In the age of 'soft steel technology' and the successful manufacturing of jute geo-textile in Bangladesh, the so-called trash of mineral sands mining can be trusted for taming the eroding river. The trash is the byproduct of mineral sands mining and that can be used to sand-cement blocks or cellular concrete, a substitute of bricks. Considering the VHM's content in the Tista River sand deposits it is not remarkable but the finding of thorium which is on the average 28 grams per ton in the bulk sand is the most remarkable. The literature review information suggests that thorium will be the source of enormous green energy in the future and it will be safe, simple and cheap. The thorium bearing minerals are heavy minerals and are very easy to collect and be separated as non-magnetic minerals. Solvent extraction is an effective method of separating the crude thorium products resulting from the acid and caustic steps $[16,17]$

The prospect of nuclear element like uranium has become bleak for its hazard and due to technological development, the prospect of nuclear energy from thorium has become bright [18]. To understand the amazing thorium resource in the Tista River sand it is tempted to mention the fuel comparison by European Nuclear Society (ENS): One kg of fire wood can produce $4.5 \mathrm{~kW} / \mathrm{h}$ electricity, one $\mathrm{Kg}$ coal can produce $6.7 \mathrm{~kW} / \mathrm{h}$ of electricity, one $\mathrm{kg}$ oil can produce $12 \mathrm{~kW} / \mathrm{h}$ electricity and one $\mathrm{kg}$ of uranium can produce $45,000 \mathrm{~kW} / \mathrm{h}$ of electricity [19] and thorium can produce 200 to 300 times more electricity than the uranium.

It is known that thorium minerals are occupied in West Bengal of India. The Geological Survey of Bangladesh has found monazite in the Brahmaputra-Jamuna River sand deposits which result is qualitative and present finding of thorium in the Tista River 
sand deposits is quantitative. The present study has found 28 grams of thorium per ton in the bulk sand deposits, which is equivalent to 1,120 grams per ton of uranium and this quantity of uranium is equivalent to 18.6 tons of bituminous coal.

\subsection{Capital cost}

The accuracy of capital cost estimates depends on the level of detail defined for the scope and engineering. For example, a preliminary scoping study may be developed by factoring costs from similar projects. This is a first pass preliminary techno-economic evaluation based on the current definition of the conceptual nature of the project. In general, the capital cost of a mineral sands project includes the following costs (Cost Estimation Handbook by Mineral Deposits Ltd):

- Administrative and laboratory facilities

- Administration during development and construction phase

- Concentrator and equipment

- Dredge and mining equipment

- Environmental planning, management, and infrastructure

- Exploration

- Finance during the development phase, including legal costs and banking fees

- Logistics and transport infrastructure

- Mobile equipment

- Power supply

- Social management planning and infrastructure

- $\quad$ Start-up (commissioning)

- The capital cost estimate for the project is US\$22.2million (see Table 4). Accuracy of the estimate is $+30 \%$.

Table 4. Estimated capital cost for proposed project.

\begin{tabular}{ll}
\hline Item & US\$M \\
\hline Mining - dredge and services & 3.85 \\
Wet concentrator plant & 8.68 \\
Mineral separation plant & 2.54 \\
Power station & 1.5 \\
Rail/port facilities and rolling stock & 0.62 \\
Temporary construction facilities & 0.71 \\
Indirect - EPCM, commissioning and project fee & 1.73 \\
Owners costs & 1.56 \\
Estimation/design allowance & 0.56 \\
Contingency & 0.46 \\
Total & 22.21 \\
\hline
\end{tabular}


The capital cost estimate is based on all new equipment required by the Grande Cote HM Project (Price Quotation of Mineral Technologies and ASX/TSX RELEASE 16 June 2010). Experience has been used for estimating owner's costs, subcontract and material rates, productivity factors and EPCM manning requirements. Additional scope changes resulting from the recent test work have also been incorporated into the plant design and the capital estimate.

\subsection{Production}

Test-work on a series of bulk samples has determined that the project can yield a product mix of zircon, ilmenite, rutile, magnetite and garnet. Estimated average annual production rates are:

Zircon $-1,200$ tons

Ilmenite $-10,000$ tons

Rutile - 2,000 tons

Magnetite $-1,800$ tons

Garnet-14,000 tons

\subsection{Marketing}

On a global scale, planned product output from the project would represent approximately $0.1 \%$ of the world zircon production and around $0.6 \%$ of world ilmenite production which whilst low in world standards can meet the local demand which produces export-oriented ceramics (from zircon) and Ti-pigment (from ilmenite). Independent analyst TZMI spell out is forecasting long term deficits in each of the zircon, ilmenite, rutile and leucoxene markets (TZMI Global Zircon Supply/Demand to 2020). This is driven by a progressive decrease in supply from existing producers, coupled with a lack of new projects and ongoing growth in consumption. These supply deficits can only be met by the discovery and development of new resources such as the proposed project. From 2015 onwards the expectation is for a widening deficit, mainly as a result of major losses of production from existing suppliers and a lack of new projects entering the market.

\subsection{Operating cost}

For scoping studies and preliminary feasibility studies, the operating costs can be estimated by looking at comparable operations for which published data is available. The operating cost was estimated from the consumption rates of raw materials and utilities calculated from the previous simulation results. The following assumptions were made in estimating the operating cost (see Table 5). 
Table 5. Estimated operating cost for proposed project.

\begin{tabular}{|c|c|c|c|c|c|}
\hline Description & Specific units & Rate & Unit Price & Rate & US\$M \\
\hline $\begin{array}{l}\text { Power } \\
\text { Fuel (Drying fuel-gas oil } \\
\text { and Mobile } \\
\text { equipment/vehicles-gas } \\
\text { oil) }\end{array}$ & $\begin{array}{l}\mathrm{kWh} / \mathrm{t} \text { of sand } \\
\text { processed }\end{array}$ & 22 & $\begin{array}{l}\text { US } \$ / \mathrm{kWh} \\
\text { power }\end{array}$ & 0.038 & 1.26 \\
\hline Employee Costs & $\begin{array}{l}\text { Labour man } \\
\mathrm{hr} / \mathrm{t} \text { of sand } \\
\text { processed }\end{array}$ & 0.42 & US\$/man hr & 0.64 & 0.43 \\
\hline Maintenance & & & & & 0.76 \\
\hline Transportation / Shipping & & & & & 0.40 \\
\hline Other & & & & & 0.44 \\
\hline Total & & & & & 3.29 \\
\hline
\end{tabular}

Estimated operating costs have been calculated for the mining, wet concentrator, mineral separation processing operations, transportation and the support services required for the operations.

\subsection{Environmental and social}

As required under Bangladesh's Environmental Code and the Mining Convention, an Environmental and Social Impact Assessment (ESIA) will need to be made. An Environmental and Social Management and Monitoring Plan (ESMMP) will be developed based on commitments made in the ESIA. The ESMMP describes the monitoring, mitigation and management measures required during the construction, operation, decommissioning and rehabilitation phases of the project. The ESMMP provides a framework for ongoing environmental and social management and sets guidelines for development of management plans and standard operating procedures that will be developed as part of the management system. The ESMMP is a dynamic document subject to updating and adjustment following biennial review and will address key environmental and social issues including water, rehabilitation, and avoidance of settlements and appropriate compensation if temporary or permanent resettlement is required. A summary of the key project assumptions and metrics are summarized in Table 6.

Table 6. Key project assumptions and metrics.

\begin{tabular}{l|l}
\hline Item & Assumption and Metrics \\
\hline Saleable products and average & Zircon -1200 tpa \\
Annual production rates & Ilmenite $-10,000$ tpa \\
& Rutile $-2,000$ tpa \\
\hline Mineral resource estimate & Inferred Resources-1.5 billion tons at $1.8 \% \mathrm{HM}$ \\
\hline Mining rate & 1.6 Mt per year of sand \\
& Average 200 tons per hr \\
\hline
\end{tabular}




\begin{tabular}{ll}
\hline Mining method & Floating cutter suction dredging operation \\
\hline Processing method & Floating concentrator featuring banks of gravity-fed High \\
& $\begin{array}{l}\text { Capacity Spirals, followed by a land-based Mineral } \\
\text { Separation Plant which includes a Wet High Intensity } \\
\text { Magnetic Separation Plant, a zircon wet and dry processing } \\
\text { plant and an ilmenite processing plant }\end{array}$ \\
\hline Processing rate & 14 tons per hr \\
\hline Tailings disposal method & Cyclone and discharge with tailings stacker \\
\hline Product transport method & $\begin{array}{l}\text { Combination of road and rail transport in containers to Port } \\
\text { of Mongla for zircon, rutile and ilmenite }\end{array}$ \\
\hline Project execution methodology & $\begin{array}{l}\text { Engineering, Procurement and Construction Management } \\
\text { Contractor }\end{array}$ \\
\hline
\end{tabular}

Table 7. Financial/economic project summary.

\begin{tabular}{lll}
\hline Financial Summary & Unit & Per Annum \\
\hline Sales indicator & & \\
Zircon product & USD/t & USD 1,050 \\
Rutile product & USD/t & USD 840 \\
Ilmenite product & USD/t & USD 110 \\
Garnet and magnetite product & USD/t & USD 80 \\
BDT/USD exchange rate & BDT/USD & 77 \\
Zircon revenue & USD 000's & USD 1,260 \\
Rutile revenue & USD 000's & USD 1,680 \\
Ilmenite revenue & USD 000's & USD 1,100 \\
Garnet and magnetite revenue & USD 000's & USD 1,270 \\
Revenue total & USD 000's & USD 5,240 \\
Cost per ton of ROM ore & & \\
Direct Production cash costs & USD/ROM Ore & USD 13.88 \\
Total operating costs & USD/ROM Ore & USD 1.5 \\
Cost per ton of concentrate sold & & \\
Direct production cash costs & USD/t concentrate & USD \\
Total operating costs & USD/t concentrate & USD 200 \\
Profit indicators & & \\
Earnings before Int, tax, Depr \& Amort & EBITDA USD 000's & $2,749,488.00$ \\
Cash flow indicators & & \\
Capital expenditure excluding owners costs & USD 000's & $14,000,000.00$ \\
Financial statistics & & 12 \\
Net present value @ 10\% & & 14 \\
Internal rate of return (\%) & & 6 \\
Payback (from commencement of production) years & &
\end{tabular}




\section{Conclusion}

Considering the relevant factors, it may be concluded that the Tista River sand deposits may be considered as Mineral Sands Deposit and it may be an asset of Bangladesh. The authors may claim the credit having discovered such a mineral resource and any company or organization interested in mining may proceed for exploration of the mineral sands in the Tista River valley. Mining of mineral sands in the river valley will have socioeconomic development in the areas and around. The present study suggests the following outcomes.

- A huge quantity of sandy materials of the rivers will be utilized as mineral sands.

- The mineral sands would be refined as commercial and industrial grade for industrial uses.

- The heavy minerals and light minerals of the river sand can be separated through mineral processing method.

- These separated minerals will be utilized in different industries such as paint, pigment, paper, foundry, ceramics, glass, leather, shipbuilding industries etc.

- Previously it was thought that some of the heavy minerals are valuable but now days the light minerals also contain valuable elements like cesium, rubidium and lithium.

- Thorium which is on the average 28 grams per ton in the bulk sand is the most remarkable can be used for power generation alternative of hazardous Uranium.

The financial summary also shows that the capital cost of the project is 22.21 million USD and operating cost is 3.29 million USD per annum. The internal rate of return (IRR) based on the first 25 years of operation only (with no terminal value) is $14 \%$ and the projected payback period is approximately 6 years after operations commence which is potential.

\section{Acknowledgment}

The authorities of Bangladesh Council of Scientific and Industrial Research (BCSIR) are thankfully acknowledged for providing research grant. The authors are thankful to the Director of IMMM for enormous efforts during the research work. Authors are extremely grateful to other scientists, technicians and laboratory attendants of the institute for their help during field work, sample preparation and analytical services.

\section{Nomenclature}

REE- Rare earth elements

ca- circa meaning approximately

BP-Before present

IMMM-Institute of mining, mineralogy \& metallurgy

BCSIR-Bangladesh council of scientific and industrial research 
ENS-European nuclear society

VHM-Valuable heavy mineral

THM-Total heavy mineral

XRF-X-ray fluorescence spectrometer

USGS-United States Geological Survey

JSD-Japanese standard sediment

S.G-Specific gravity

ESCAP-Economic social commission for Asia-Pacific

EPCM- Engineering, procurement and construction management contractor

\section{References}

1. E. R. Force, Geology of Titanium-mineral Deposits, Geological Society of America, (special issue, 1991) pp. 112.

2. S. Mitra, S. S. Ahmed, and H. S. Moon, Sedimentary Geology 77, 235 (1992). https://doi.org/10.1016/0037-0738(92)90129-F

3. M. A. Islam, J. Ind. Assoc. Sedimentologists 16, 243 (1997).

4. Z. Bari, Z. M. Rajib, and S. M. M. Ameen, Jahangirnagar Univ. J. Sci. 34, 143 (2011).

5. M. Zaman, M. Schubert, and S. Antao, Isotopes in Environ. Health Studies 48, 512 (2012). https://doi.org/10.1080/10256016.2012.696542

6. M. A. Rahman, P. K. Biswas, M. N. Zaman, M. Y. Miah, T. Hossain, and S. M. Imamul Huq. Bang. J. Sci Ind. Res. 47, 167 (2012). https://doi.org/10.3329/bjsir.v47i1.10728

7. M. A. Rahman, M. I. Pownceby, N. Haque, W. J. Bruckard, and M. N, Zaman, Trans. Inst. Min. Metall. B 123, 222 (2014).

8. M. K. Alam, A Study on the Scope of Manufacturing of Artificial Sandstone and uses in Bangladesh, Bangladesh Geological Society (Seminar issue, 1989).

9. M. A. Rahman, Flood Control and Sediment Transportation of the Rivers of Bangladesh Proc. of the Seminar on Flood Control (1972) pp. 153-158.

10. H. Rashid, Geography of Bangladesh, (The University Press Limited, Dhaka 1000, Bangladesh, 1991) pp. 18-53.

11. J. M. Coleman, Brahmaputra River: Sedimentary Geology-Elsevier Publication Company, Special Issue, (Amsterdam, Netherlands, 1969) 3(2/3), pp. 129-239.

12. M. Umitsu, Late Quaternary Sedimentary Environment and Landform Evaluation in the Bengal Lowland (Department of Geography, Nagoya University, Nagoya, Japan, 1991) pp.165-177.

14. R. Ramesh, Distribution of Rare Earth Elements and Heavy Metals in the Surficial Sediments in the Himalayan River System (Department of Environmental Science, Jauharlal University, New Delhi, India, 2000).

15. T. Hentschel, Inst. Scientific Co-operation, Tubingen 34, 84 (1991).

16. W. S. Kirk, Mineral Facts and Problems (United States Department of Interior, 1980).

17. Mineral Sands in Asia and the Pacific, United Nations, Economic and Social Commission or Asia and the Pacific, Bangladesh, 04, 45 (1990).

18. M. A. Rahman, Jahangirnagar Univ. Phy. Studies 19, 79 (2013).

19. Fuel comparison by European Nuclear Society (ENS).

20. Mineral Deposits Limited, ASX/TSX RELEASE (2010).

21. TZMI Global Zircon Supply/Demand to 2020.

22. Cost Estimation Handbook by Mineral Deposits Ltd. (2010). 